\title{
THE EFFECT OF 5-BROMO-2-THIENYL-ETHYL KETONE THIOSEMICARBAZONE ON THE INDUCED DECIDUOMAL RESPONSE IN THE RAT
}

\author{
FRANK G. TINSLEY, ROBERT P. RATHMACHER \\ AND ROBERT L. COCHRANE \\ Lilly Research Laboratories, Eli Lilly and Company, \\ Indianapolis, Indiana 46206, U.S.A.
}

(Received 23rd December 1968)

\begin{abstract}
Summary. The effect of 5-bromo-2-thienyl-ethyl ketone thiosemicarbazone (70026) on the deciduomal response was studied to determine the mode of its antifertility activity. The study utilized intact, ovariectomized and hypophysectomized rats that were made pseudopregnant and/or treated with progesterone, corn oil, prolactin and 70026, either alone or in combination. The results indicated that 70026 partially inhibited the deciduomal response by a direct action on the uterus, but also had an additional inhibitory effect by a direct action on the ovary. This latter effect indicated that 70026 inhibited progesterone synthesis and/or secretion from the corpus luteum, or interfered with luteotrophin stimulation of the ovary. Compound 70026 had no significant effect on ovarian weight but it did have a highly significant effect on body weight.
\end{abstract}

\section{INTRODUCTION}

Routine screening of compounds for antifertility effects in rats led to the discovery that a series of thiophene thiosemicarbazones possessed antifertility activity. The most promising of the series studied to date has been 5-bromo-2thienyl-ethyl ketone thiosemicarbazone (70026). Preliminary studies on this compound showed that it was active when administered post coitum and inhibited or delayed ovo-implantation. Cursory observations indicated that progesterone administration would offset this antifertility effect. The compound caused continued oestrous cycles in pseudopregnant and pregnant rats, as judged by vaginal smear cytology. These preliminary findings seemed to indicate that 70026 was having its antifertility effect by interference with progesterone synthesis, secretion or utilization.

This study was the first in a series to determine whether or not 70026 was, in fact, having these effects, and, if so, the level at which it acted. The deciduomal reaction was used as the model for studying the antifertility action of 70026 , since it provided a means for assessing: (1) the presence of progesterone in the circulation (Astwood, 1939; Rothchild, Meyer \& Spielman, 1940), (2) the 
utilization of progesterone at the target organ (Astwood, 1939; Rothchild et al., 1940) and (3) the function of many of the factors presumed to be involved in ovo-implantation (Shelesnyak, 1957; Shelesnyak \& Kraicer, 1963; Finn \& Keen, 1963; Finn, 1966).

\section{MATERIALS AND METHODS}

The animals used in these studies were mature female Carworth CFE strain rats which were maintained on Purina Lab Chow and tap water. They were housed separately, or in groups of up to six animals per cage, at a constant temperature $\left(74\right.$ to $\left.76^{\circ} \mathrm{F}\right)$ and on a regimen of $14 \mathrm{hr}$ light and $10 \mathrm{hr}$ dark. The animals completed at least three normal 4- to 5-day oestrous cycles before being put on the experiment. Pseudopregnancy was induced by uterine cervical stimulation with a glass rod on the morning and evening of the day of oestrus. Surgical procedures were performed under ether anaesthesia using a semi-sterile technique. Ovariectomy was carried out through dorso-lateral incisions, while the parapharyngeal approach was used for hypophysectomy. Uterine trauma was accomplished through a mid-ventral incision by scratching the entire length of the anti-mesometrial side of the left uterine horn with a burred needle. Progesterone and 5-bromo-2-thienyl-ethyl ketone thiosemicarbazone (70026) were each injected subcutaneously (s.c.) at a daily dose of $2 \mathrm{mg}$ in $0 \cdot 1$ $\mathrm{ml}$ corn oil. Gorn oil alone was administered as a daily $0.1 \mathrm{ml}$ s.c. injection. Prolactin (ovine, 14 i.u. $/ \mathrm{mg}$ ) was given as twice daily s.c. injections of 5 i.u. in $0.1 \mathrm{ml}$ of $0.9 \%$ saline; except for the first and last day of treatment when it was given only once a day.

All animals were started on the experiment on the last day of oestrus (Day 1). Ovariectomy and hypophysectomy were carried out on the afternoon of Day 1. Pseudopregnancy, likewise, was induced on Day 1. Injections were begun on the afternoon of Day I and continued through to the morning of Day 10. All animals had one uterine horn injured on Day 5 and were killed on the afternoon of Day 10. The specific treatment regimens of each group appear in Table 1.

Body weights were recorded at the beginning of the experiment, at the time of uterine trauma and at autopsy. Animals with infections and hypophysectomized animals possessing macroscopic pituitary remnants in the sella turcica were discarded from the experiment. The ovaries were removed and weighed at autopsy. The two uterine horns were, likewise, removed at this time, evaluated grossly for the presence or absence of a deciduomal response and weighed separately. All uterine horns and ovaries were preserved in Bouin's fluid. Later, the injured uterine horns of four rats from each of Groups 1 and 2, three rats from each of Groups 5, 6, 7, 9 and 10 and eight rats from Group 8 were sectioned, mounted, stained with haematoxylin and eosin, and evaluated histologically. Horns where obvious deciduomal reactions existed had nine sections cut from the deciduomal area; horns where the presence of deciduomal reactions was in doubt had nine sections cut from each of three entirely different areas. In all cases, the uterine horns thought most likely to contain deciduomal responses were the ones selected from the group for histological study. Four representative sections from each of the left ovaries of forty of the animals were, 
likewise, prepared and studied histologically. These forty rats consisted of six rats from Group 8, four rats from Group 1 and three each from Groups 2, 3, 4, $7,9,10,11,12,15$ and 16 .

Comparisons between groups were made using the difference in weight of the injured and uninjured uterine horns as the measure of the deciduomal response, since uterotrophic effects of the treatment should be reflected in the weight of the uninjured uterine horn. Ovarian weight, expressed as the mean total weight of both ovaries, and change in body weight during the treatment were also compared. Analyses of variance of all data and, in the case of the uterine weight differences and ovarian weights, a further Duncan's Multiple Range Test, were calculated (Steel \& Torrie, 1960). The Duncan's Multiple Range Test was modified by using the harmonic mean in calculating the standard error. Because of a positive correlation between means and their respective standard deviations in the uterine weight data, the responses were converted to natural logarithms before analysis. In contrast to this, the absolute values were used in the analysis of ovary weights and change in body weight. In the latter data, there were three observations missing in each of Groups 7 and 8 and one in each of Groups 9 and 12. One additional observation was omitted from Group 8 because it alone caused significant heterogeneity of variance in this data.

Six of the sixteen animals in Group 1 were injected with corn oil daily, while the other ten received no injections at all. These two sub-groups were compared to check for a placebo effect. There was no significant difference in the two

TABLE 1

EFFECTS OF 70026 ON WEIGHT DIFFERENCES BETWEEN THE INJURED AND UNINJURED UTERINE HORNS, OVARIAN WEIGHTS AND GHANGES IN BODY WEIGHTS

\begin{tabular}{|c|c|c|c|c|c|}
\hline $\begin{array}{c}\text { Group } \\
\text { no. }\end{array}$ & $\begin{array}{c}\text { No. of } \\
\text { animals }\end{array}$ & Treatment & $\begin{array}{c}\text { Mean difference } \\
\text { in the two } \\
\text { uterine horns } \\
\text { (mg) }\end{array}$ & $\begin{array}{l}\text { Mean ovarian } \\
\text { weight (tolal } \\
\text { of both } \\
\text { ovaries in } \\
\text { mg) }\end{array}$ & $\begin{array}{c}\text { Mean } \\
\text { change } \\
\text { in body } \\
\text { wt }(g)\end{array}$ \\
\hline $\begin{array}{r}1 \\
2 \\
3 \\
4 \\
5 \\
6 \\
7 \\
8 \\
9 \\
10 \\
11 \\
12 \\
13 \\
14 \\
15 \\
16\end{array}$ & $\begin{array}{l}16(16)^{*} \\
10(10) \\
10(10) \\
10(10) \\
10(10) \\
11(11) \\
10(7) \\
11(7) \\
10(9) \\
10(10) \\
5(5) \\
6(5) \\
5(5) \\
5(5) \\
10(10) \\
10(10)\end{array}$ & $\begin{array}{l}\text { Psp } \\
\text { Psp }+70026 \\
\text { Prl } \\
\text { Prl }+70026 \\
\text { Ovx + Prg } \\
\text { Ovx + Prg + 70026 } \\
\text { Apx + Prl } \\
\text { Apx + Prl + 70026 } \\
\text { Apx + Prg } \\
\text { Apx + Prg + 70026 } \\
\text { Apx+ Corn oil } \\
\text { Apx+ 70026 } \\
\text { Ovx+ Corn oil } \\
\text { Ovx + 70026 } \\
\text { Prg } \\
\text { Prg + 70026 }\end{array}$ & $\begin{array}{r}1425 \\
56 \\
1674 \\
41 \\
846 \\
179 \\
748 \\
46 \\
697 \\
151 \\
16 \\
12 \\
5 \\
6 \\
1203 \\
312\end{array}$ & $\begin{array}{l}77 \cdot 2 \\
69 \cdot 3 \\
73 \cdot 3 \\
74 \cdot 3 \\
- \\
\overline{47 \cdot 6} \\
46 \cdot 6 \\
53 \cdot 6 \\
50 \cdot 8 \\
55 \cdot 5 \\
47 \cdot 6 \\
\overline{-} \\
68 \cdot 7 \\
66 \cdot 7\end{array}$ & $\begin{array}{l}+13 \cdot 3 \\
+4 \cdot 1 \\
+12 \cdot 4 \\
+5 \cdot 2 \\
+14 \cdot 8 \\
+10 \cdot 4 \\
-13 \cdot 0 \\
-15 \cdot 4 \\
-16 \cdot 1 \\
-23 \cdot 0 \\
-22 \cdot 6 \\
-29 \cdot 0 \\
+9 \cdot 6 \\
+6 \cdot 4 \\
+21.7 \\
+9.6\end{array}$ \\
\hline
\end{tabular}

Psp = pseudopregnant $;$ Apx = hypophysectomized Ovx = ovariectomized $; \operatorname{Prg}=$ progesterone; $\mathrm{Prl}=$ prolactin.

* Number in parentheses represents the number of observations involved in the change in body weight. 
sub-groups in any of the end-points studied so they were pooled and used as one group.

\section{RESULTS}

The results showed that 70026, in all cases except those of the negative controls (Groups 11, 12, 13 and 14), significantly reduced $(P<0.01)$ the deciduomal response below that of their respective controls (Tables 1 and 2). It was evident from the weight differences in the two uterine horns, as well as gross evaluation of the uteri, that deciduomal responses had not occurred in any of the negative control groups, thus explaining the lack of effect of 70026 in these groups. The results of the analysis of the deciduomal response (Table 2) demonstrate quite convincingly that 70026 was acting both at the uterine level and at the ovarian level to reduce or inhibit the deciduomal response. The effect at the uterine level was shown by the fact that 70026 significantly reduced $(P<0.01)$ the deciduomal response in progesterone-treated animals compared with animals not receiving 70026 (Groups 6,10 and 16 versus Groups 1, 3, 5, 7, 9 and 15). An additional effect at the ovarian level was indicated by the fact that 70026-treated animals depending on endogenous sources for their progesterone (Groups 2, 4 and 8) had significantly smaller $(P<0.01)$ deciduomal responses than 70026-treated animals receiving exogenous progesterone (Groups 6, 10 and 16). This was particularly striking in comparing the hypophysectomized luteotrophin (prolactin)-treated (Group 8) with the hypophysectomized progesterone-treated (Group 10) animals. The other differences that existed between groups in this end-point (i.e. Group 3 versus 9; Group 13 versus 2, 4 and 8; and Group 14 versus 2 and 8 ) were not so clear-cut and explanations for them are purely speculative. The uterine weight data from the negative controls, both from the standpoint of the individual means and the comparisons of 70026-treated with non-treated groups, demonstrates that 70026 itself did not support the deciduomal response and, for that matter, had little effect on the response of the uterus to trauma in the absence of progesterone.

The uteri that were examined from the animals in Groups 1, 5, 7 and 9 all contained large, fully-developed deciduomata consisting of both the large, anti-mesometrial, binucleate type of stromal cell and the smaller, mesometrial, vacuolated type of stromal cell, similar to those described by Krehbiel (1937) and Selye \& McKeown (1935). By contrast, all uteri examined from animals in Groups 6 and 10 contained very small deciduomata usually consisting of only small sub-epithelial plaques of the anti-mesometrial type of binucleate decidual cell. The uteri that were examined from Groups 2 and 8 contained only small deciduomata, similar to those in Groups 6 and 10, or no deciduomata at all. In the latter cases, there were usually some pycnotic epithelial and stromal cells and a number of erythrocytes and polymorphonuclear leucocytes in the tissue spaces and uterine lumen associated with the uterine trauma. In general, the histological evaluation of the uterus as to the presence or absence and extent of the deciduomal response roughly parallels the results obtained using the weight difference in the injured and uninjured uterine horns.

Treatment with 70026 did not have any apparent effect on ovarian weight 


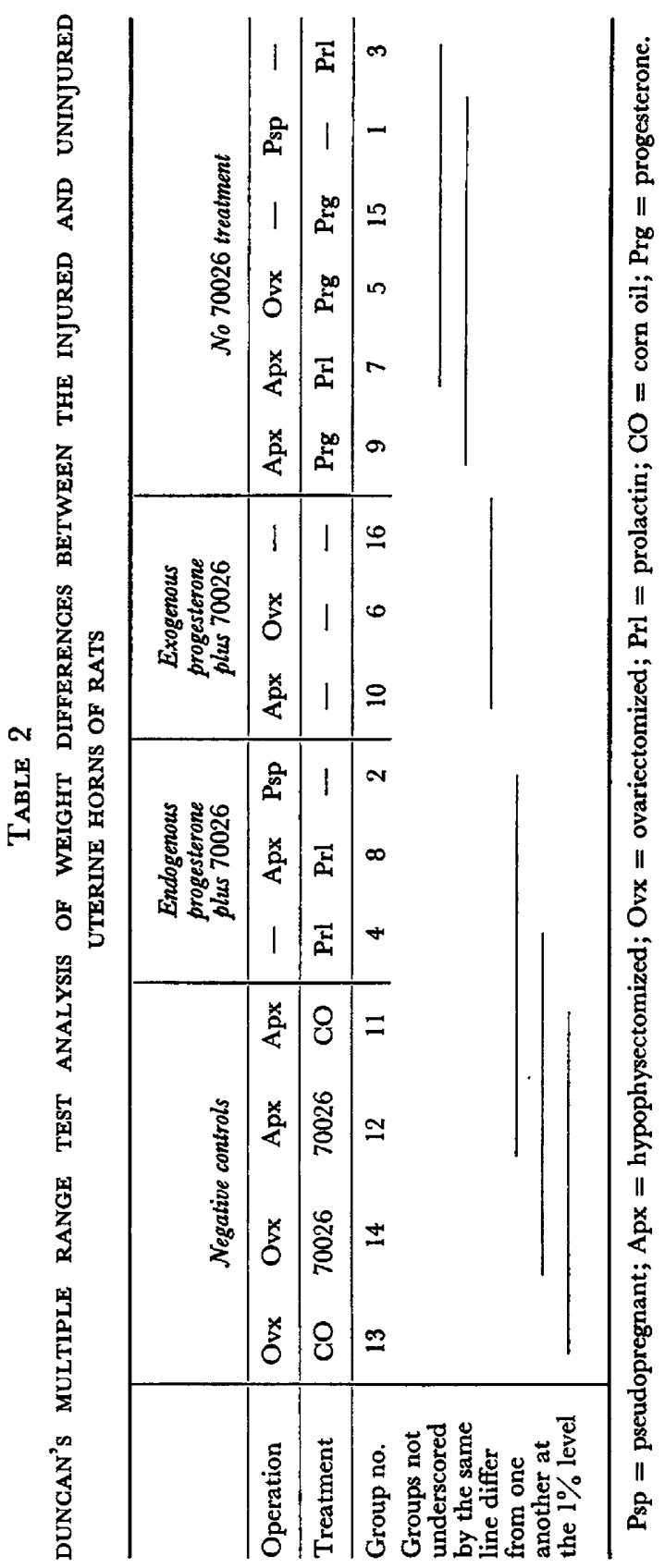


(Table 3). The hormonal-surgical treatments, however, did have a highly significant $(P<0 \cdot 0005)$ effect. It is evident from Tables 1 and 3 that this effect was caused mostly by the surgical procedure of hypophysectomy reducing the ovarian weight. When the $5 \%$ probability level was used as the level of significance, this effect was quite clear-cut. When the $1 \%$ level was used, however, some overlap occurred between the intact and hypophysectomized animals and the difference due to this operation was not quite so obvious.

TABLE 3

DUNGAN'S MULTIPLE RANGE TEST ANALYSIS OF OVARIAN WEIGHTS

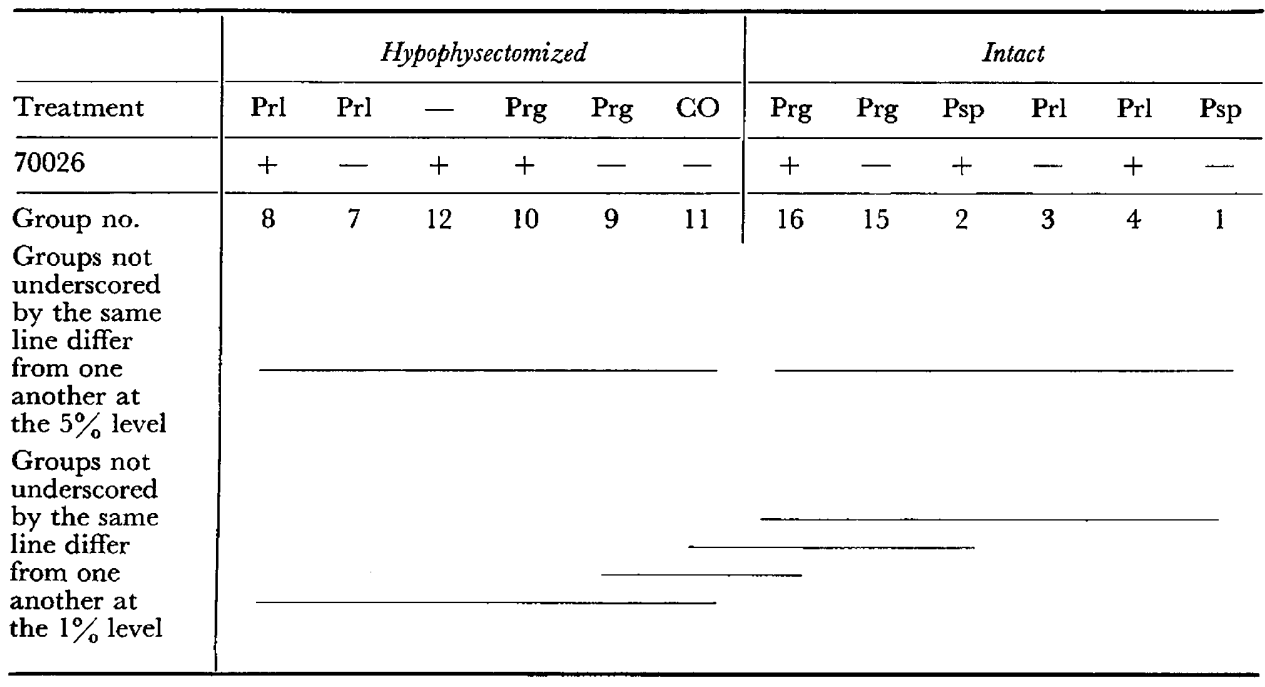

Psp = pseudopregnant $;$ Prg $=$ progesterone $; \operatorname{Prl}=$ prolactin $; \mathrm{CO}=$ corn oil.

Subjective evaluation of the ovaries from the animals in this experiment indicated that 70026 treatment had little or no obvious effect on ovarian histology, with the possible exception of Group 8. The corpora lutea from the animals in this group may have contained a few more pycnotic and vacuolated luteal cells than their controls but this was not very clear-cut. By contrast, progesterone treatment seemed to have a definite effect on the corpus luteum morphology. It apparently caused the cytoplasm of many of the luteal cells to be more vacuolated in some cases and contain fewer granules in other cases. As a result, many of the luteal cells from the progesterone-treated animals were very lightly stained. Connective tissue invasion of the corpora lutea was also more evident in progesterone-treated animals than in those which were not treated with progesterone. Hypophysectomy caused a slight reduction in size of the corpora lutea and the luteal cells and also seemed to reduce the number and size of the vesicular follicles in the ovary. These latter structures were almost invariably atretic in all the ovaries examined. Prolactin seemed to increase the size of the corpora lutea and the luteal cells in both intact and hypophysectomized animals; while corn oil had no obvious effect on ovarian histology.

The mean changes in body weight (Table 1) indicated that 70026 treatment 
caused a reduction in body weight. An analysis of variance of the data showed that this tendency was highly significant $(P<0 \cdot 0005)$. This analysis also showed that the other hormonal-surgical treatments considered collectively had a highly significant effect $(P<0.0005)$ on body weight change. There was no significant $(P>0.05)$ interaction, however, between the 70026 treatment and the collective hormonal-surgical treatments. No attempt was made to determine specific group differences, since the purpose of this part of the experiment was only to obtain some crude measurement of the effect of 70026 on body weight.

\section{DISCUSSION}

The deciduomal response in the rat is apparently specific for progesterone (or progestin) conditioning of the uterus; however, oestrogen has a marked quantitative influence on this reaction (Astwood, 1939; Rothchild et al., 1940; Yochim \& De Feo, 1962, 1963). The present experiments attempted to utilize the deciduomal response quantitatively to partition out the level at which 70026 was acting. It was suspected that progesterone was the factor affected; therefore, progesterone alone was used as the exogenous steroid supplied in spite of the known effects of oestrogen. Fortunately, the interaction of endogenous oestrogen with progesterone did not prevent the partitioning of the level of effect of the 70026. Quite probably this interaction was the reason for the high values obtained for the deciduomal responses in the intact animals not treated with 70026 (Groups 1, 3 and 15). The daily prolactin dose (Malven, Hansel \& Sawyer, 1967) given to the hypophysectomized animals seems to have approximated very closely to the effect of the exogenous progesterone in the ovariectomized and hypophysectomized animals. This prolactin effect was assumed to be caused by endogenous progesterone alone without the interaction of oestrogen.

The use of the deciduomal response as a method of assessing corpus luteum function is certainly nothing new (Evans, Simpson, Lyons \& Turpeinen, 1941; Everett, 1954); neither is the use of this same end-point as a method of studying the antifertility effect of numerous compounds (Duncan, Cornette, Lyster, Northam \& Wyngarden, 1966; Duncan, Wyngarden \& Cornette, 1968; Harper, 1967; Lindsay, Poulson \& Robson, 1961 ; Schlough \& Meyer, 1965; Shelesnyak, 1965). Most of the studies on inhibition of the deciduomal response have demonstrated an action directly at the level of the uterus. Such studies were those on the classical oestrogens (Astwood, 1939; Rothchild et al., 1940; Velardo \& Hisaw, 1951; Yochim \& De Feo, 1962), some of the newer impeded oestrogens (Duncan et al., 1968; Schlough \& Meyer, 1965), oxazolidinethione (Duncan et al., 1966), some of the pregnanes, testosterone and some of the mineralo- and gluco-corticoids (Hisaw \& Velardo, 1951). A few of the deciduomal studies, on the other hand, have shown (Lindsay et al., 1961, 1962), or indicated (Harper, 1967; Shelesnyak, 1957), an action by the inhibitory agents at some level other than that of the uterus (see also Lindner \& Shelesnyak, 1967). None of these studies have demonstrated specifically the site of the inhibitory activity of the agents, but most of them suggest an action on the central ner- 
vous-pituitary system and/or the ovary. By contrast, the present study has not only demonstrated a site of action directly at the uterine level itself, but has also defined a specific site of action outside the uterus, namely, the ovary.

Compound 70026 seems to be a unique compound. Unlike many of the deciduomata-inhibiting compounds mentioned previously, neither of the activities of 70026 seemed to be attributable to its oestrogenicity. Treatment of hypophysectomized (Group 12) or ovariectomized (Group 14) rats with 70026 did not cause an increase in uterine weight over that caused by corn oil alone (Groups 11 and 13, respectively). The average weights of the uninjured uterine horns of each of the above groups was $67,105,92$ and $117 \mathrm{mg}$, respectively. The data in Table 3 suggest, in addition, that 70026 does not act on the deciduomal response by stimulating or depressing the pituitary gonadotrophins. The direct effect of 70026 on the ovary to inhibit deciduomata formation further demonstrates the uniqueness of this compound when compared with previously reported deciduomata-inhibiting compounds. This latter activity would appear to be best explained by an inhibition of progesterone synthesis and/or secretion by the corpus luteum, or interference with the action of luteotrophin at the target tissue. The reports by Schuler \& Meier (1951) (cited in Gaunt, Chart \& Renzi, 1961) and Gaunt et al. (1961) that 5-chloro-2acetyl-thiophene thiosemicarbazone depresses adrenal cortical function seems to give additional support to this suggested interference with steroidogenesis by 70026.

\section{ACKNOWLEDGMENTS}

We would like to thank Dr J. Bastian, Armour Pharmaceutical Company, Kankakee, Illinois, for the generous gift of prolactin used in this study. We are also indebted to Dr D. M. Brennan and Dr M. X. Zarrow for helpful advice and suggestions, to Mr D. R. Bennett, Mr G. J. Shaar and Mr E. B. Smalstig for technical assistance, $\mathrm{Mr} \mathrm{R}$. Edie for synthesizing and supplying the 5-bromo-2thienyl-ethyl ketone thiosemicarbazone and to Mr G. C. Adams for the histological preparations.

\section{REFERENCES}

Astwood, E. B. (1939) An assay method for progesterone based upon the decidual reaction in the rat. 7. Endocr. 1, 49.

Duncan, G. W., Cornette, J. C., Lyster, S. C., Northam, J. I. \& Wyngarden, L. J. (1966) Biochemical aspects of rat deciduomata as affected by an oxazolidinethione. Am. F. Physiol. 211, 184.

Duncan, G. W., Wyngarden, L. J. \& Cornette, J. C. (1968) Interaction of oestradiol and nafoxidine hydrochloride with progesterone in deciduomata formation. 7. Reprod. Fert. 15, 53.

Evans, H. M., Simpson, M. E., Lyons, W. R. \& Turpeinen, K. (1941) Anterior pituitary hormones which favor the production of traumatic uterine placentomata. Endocrinology, 28, 933.

Everett, J. W. (1954) Luteotrophic function of autografts of the rat hypophysis. Endocrinology, 54, 685.

Fins, C. A. (1966) The initiation of the decidual cell reaction in the uterus of the aged mouse. $\mathcal{F}$. Reprod. Fert. 11, 423.

Finn, C. A. \& Keen, P. M. (1963) The induction of deciduomata in the rat. 7. Embryol. exp. Morph. 11, 673.

Gaunt, R., Chart, J. J. \& Renzi, A. A. (1961) Endocrine pharmacology. Science, N.Y. 133, 613.

HARPER, M. J. K. (1967) Maintenance by oestrone and progesterone of deciduomal growth in rats given methallibure (I.C.I. 33,828). Acta endocr., Copenh. 54, 249.

Hisaw, F. L. \& VeLardo, J. T. (1951) Inhibition of progesterone in decidual development by steroid compounds. Endocrinology, 49, 732. 
KREHBIEL, R. H. (1937) Cytological studies of the decidual reaction in the rat during early pregnancy and in the production of deciduomata. Physiol. Zoöl. 10, 212.

LiNDNER, H. R. \& SHELESNYAK, M. C. (1967) Effect of ergocornine on ovarian synthesis of progesterone and 20x-hydroxy-pregn-4-en-3-one in the pseudopregnant rat. Acta endocr., Copenh. 56, 27.

Lindsay, D., Poulson, E. \& Robson, J. M. (1961) The effect of 5-hydroxytryptamine and of an amine oxidase inhibitor on experimental deciduomata in mice. F. Endocr. 23, 209.

Lindsay, D., Poulson, E. \& Robson, J. M. (1962) Interrelation between progesterone, 5-hydroxytryptamine and HP1325 in the decidual response in ovariectomized mice. F. Endocr. 25, 53.

Malven, P. V., Hansel, W. \& Sawyer, C. H. (1967) A mechanism antagonizing the luteotrophic action of exogenous prolactin in rats. F. Reprod. Fert. 13, 205.

RothCHID, I., MEYER, R. K. \& SPIELMAN, M. A. (1940) A quantitative study of oestrogen-progesterone interaction in the formation of placentomata in the castrate rat. Am. F. Physiol. 128, 213.

Schlough, J. S. \& Meyer, R. K. (1965) Suppression of the decidual response with estrogen antagonists. Fert. Steril. 16, 596.

Selye, H. \& MaKeown, T. (1935) Studies on the physiology of the maternal placenta in the rat. Proc. R. Soc. B, 119, 1.

ShELESNYAK, M. C. (1957) III. Aspects of reproduction. Some experimental studies on the mechanism of ova-implantation in the rat. Recent Prog. Horm. Res. 13, 269.

ShelesNyak, M. C. (1965) Inhibition of decidualization. In: Biological Council Symposium on Agents Affecting Fertility. Ed. C. R. Austin and J. S. Perry. Churchill, London.

Shelesnyak, M. G. \& Kraicer, P. F. (1963) The role of estrogen in nidation. In: Delayed Implantation. Ed. A. C. Enders. University of Chicago Press.

Steel, R. G. D. \& Torrie, J. H. (1960) Principles and procedures of statistics with special reference to the biological sciences. McGraw-Hill, New York.

Velardo, J. T. \& Hisaw, F. L. (1951) Quantitative inhibition of progesterone by estrogens in development of deciduomata. Endocrinology, 49, 530.

Yoснiм, J. M. \& De Feo, V. J. (1962) Control of decidual growth in the rat by steroid hormones of the ovary. Endocrinology, 71, 134.

Yochm, J. M. \& De FEo, V. J. (1963) Hormonal control of the onset, magnitude and duration of uterine sensitivity in the rat by steroid hormones of the ovary. Endocrinology, 72, 317. 